\title{
Comparison Between Two Energy Dynamic Tools: the Impact of Two Different Calculation Procedures on the Achievement of nZEBs Requirements
}

\author{
Laura Pompei ${ }^{1}$, Fabio Nardecchia ${ }^{1}$, Benedetta Mattoni ${ }^{1}$, Fabio Bisegna ${ }^{1}$, Alessandro Mangione ${ }^{1}$ \\ ${ }^{1}$ Sapienza University of Rome, Rome, Italy
}

\begin{abstract}
Due to the limitations of the stationary energy needs calculation, energy dynamic simulation tools become strictly essential. In literature, many researches compared different energy simulation tools without validating those models through real data. In this framework, this study aims to compare two energy dynamic simulation tools: TRNSYS 16 and Grasshopper/Archsim, through a real case study, the historical building of Palazzo Baleani, validated by comparing the simulated results with real consumptions. Furthermore, results will help users to choose the most suitable software depending on the needs and the available data. Finally, latest analysis underline that different type of retrofit solutions, simulated with those two tools, have a considerable impact on the achievement of nZEBs targets, especially on the listed building.
\end{abstract}

\section{Introduction}

A new European regulation EN ISO 52016-1:2017 concerning the calculation procedures of building energy needs, heat loads and internal temperatures, was issued. This standard represents a turning point in the calculation methods since it is based on hourly or monthly dynamic calculations instead of the stationary calculation as in the UNI/TS 11300 (UNI/TS 2014). In fact, dynamic simulations allow to control and manage the complexity of a real environment, such as the occupant behaviour, the thermal inertia of the envelope and the use of hourly climate data values. Last year, the EN ISO 52016-1:2017 was approved as a directive UNI EN ISO 52016-1:2018, therefore the interest on the energy dynamic tools are growing. In this framework, this research aims to compare the accuracy of two energy dynamic simulation tools and their graphic interfaces: TRNSYS 16, with TRNSYS Simulation Studio as graphic interface, and Archsim with Grasshopper as interface and Energy Plus as calculation engine. The aim of this work is to underline the weaknesses and the strengths of those two simulation tools and analyse the input and output conditions, modelling a real case study. Most energy simulation tools, such as TRNSYS and EnergyPlus, are validated by the IEABESTEST (International Energy Agency Building Energy Simulation Test and Diagnostic Method) procedures (Neymark and Judkoff, 2008), but frequently reliable results are not provided for the last version of these software (Gasparella and Pernigotto, 2010).

On the other side, open sources software as Grasshopper, are easily implemented by the users, but few of them are validated. Therefore, the comparison between TRNsys, software validated by international procedures, and the energy open source Grasshopper/Archsim could be a useful step through the free plug-in valuation. Furthermore, many researches in literature compared building energy performance obtained with different simulation tools but frequently these energy models are not validated using real data (Mauri, 2016). Due to the wide variety of the cultural heritage in Italy, an historic building is chosen as a case study. It is Palazzo Baleani, an historical structure (Decreto Legislativo 2004) located in the centre of Rome. In fact, today the need of including the cultural heritage into the policies of energy efficiency has become a relevant issue of European legislation (Mazzarella, 2015) according to the Directive 2010/31/UE EPBD recast (European Parliament Directive 2010). Moreover, this directive highlights the importance of promoting the transformation of existing buildings into Nearly Zero Energy Buildings (nZEBs). An NZEB is a "very high energy performance building", which cover a very significant extent of building energy needs with renewable energy sources, partially produced on site or nearby the building. According to this, it is important to investigate how and if historical structures can comply with nZEBs target; in fact, many researches underlined that it is very difficult for these buildings to conform with nZEBs requirements (Testi et al, 2017), due to the numerous restrictions imposed on ancient buildings. Therefore, the last step of this research consists on performing energy analysis in order to evaluate if and to what extent different type of passive and renewable retrofit solutions would allow to achieve nZEBs targets on this type of historical building.

\section{Methodology}

This study aims to compare two energy dynamic tools: TRNSYS 16 and Grasshopper/Archsim in order to highlight many aspects of those two tools and to provide suggestions for choosing the most suitable software depending on the specific needs and the available data. Model validation is guaranteed by the calibration of those simulations results with the real energy consumptions of the case study. Passive and renewable retrofit solutions proposed are in line with the capacity 
of both energy tools, in order to compare them properly. Finally, it will be assessed if the analysis of these differences would influence in the achievement of the nZEBs requirements. The main steps of the work are the followings:

1. Case study ex ante analysis

2. Case study ex post analysis trough passive and renewable retrofit strategies

3. Model validation trough the comparison between ex ante results and energy consumption of the specific year 2014.

4. Impact of different type of retrofit solutions to achieve nZEBs targets

\section{Energy dynamic tools}

TRNSYS (TRaNsient SYstem Simulation program) is an energy simulation tool created by "Solar EnergyLaboratory" University of Wisconsin-Madison, USA. It is composed by two parts: the first is the proper engine which receives the inputs and iteratively solves the system by reaching convergence; the second is the library of components which allows to model the performance of the system. The software includes (TRNSYS 16, Manual):

- TRNBuild is the specific tool for modelling the building properties such as building materials, profiled of occupancy, ventilations rate, loads and internal gains and so on.

- Typestudio is the proper engine which includes a FORTRAN77 mathematical codes and a graphical interface for developing new blocks or compiling the existing one, in order to create the entire model.

- TRNEdit is the text editor for writing and viewing TRNSYS input and output files.

Archsim Energy Modeling is a plug-in for the parametric design environment Grasshopper for Rhinoceros (Dogan, 2013). The thermal model class library contains abstract definitions for zones, faces, materials and can translate those into a simulation engine specific syntax (Dogan et al, 2015). Recently, it becomes a part of the DIVA environmental performance analysis suite (Alstan Jakubiec and Reinhart, 2011). Below the description of those tools:

- Grasshopper is a graphical algorithm interface, free plug in for Rhinoceros. This tool uses a nodes diagram to describe mathematics and geometrical relationships.

- Rhinoceros 3D is a CAD modelling software for architectural and design fields, that works with NURBS (Non-uniform Rational BSplines). This program allows to support a large amount of environmental and energy free plugin.
- EnergyPlus is the Grasshopper/Archsim energy engine for the analysis and thermal load simulation, elaborated by the U.S. Department of Energy's (DOE) Building Technologies Office (BTO) and managed by the National Renewable Energy Laboratory (EERE 2013).

\section{Case study}

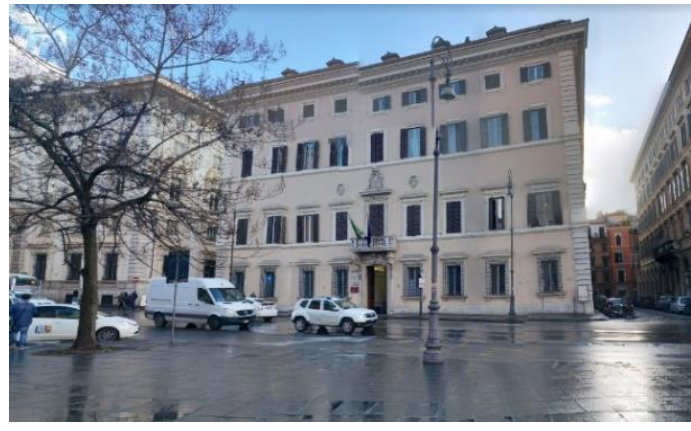

Figure 1: Palazzo Baleani

The case study is the historical building of Palazzo Baleani, Figure 1. Located in the city centre of Rome, it was built in the first quarter of the sixteenth century. It is composed by four floors with an average height of 3.7 $\mathrm{m}$. The building is occupied by offices, but it hosts university lessons and research activities too. The building has a very old envelope and consequently very low performance. Table 1 summarizes the properties of the envelope.

Table 1: Characteristics of the envelope

\begin{tabular}{|c|c|c|c|}
\hline Type & $\begin{array}{c}\text { Thickness } \\
(\mathrm{m})\end{array}$ & Description & $\begin{array}{c}\text { Trasmittance } \\
\left(\mathrm{W} / \mathrm{m}^{2} \mathrm{~K}\right)\end{array}$ \\
\hline $\begin{array}{c}\text { Perimeter } \\
\text { walls }\end{array}$ & 1 & $\begin{array}{c}\text { Load bearing } \\
\text { walls }\end{array}$ & 0.8 \\
\hline $\begin{array}{c}\text { Internal } \\
\text { walls }\end{array}$ & 1 & $\begin{array}{c}\text { Load bearing } \\
\text { walls }\end{array}$ & 0.8 \\
\hline Partitions & 0.2 & PVC & 0.704 \\
\hline Floor & 0.9 & $\begin{array}{c}\text { Iron beams } \\
\text { and hollow } \\
\text { bricks }\end{array}$ & 0.367 \\
\hline Roof & 0.9 & $\begin{array}{c}\text { Tiles and } \\
\text { reinforced } \\
\text { concrete }\end{array}$ & 0.448 \\
\hline
\end{tabular}

Single-glazed windows with different shapes and dimensions are installed on the facades of the building: Table 2 shows the percentage glass surfaces for each orientations and floors.

Table 2-Characteristics of the windows

\begin{tabular}{|c|c|c|c|c|c|}
\hline Floor & $\begin{array}{c}\text { Total } \\
\text { surfaces } \\
\left(\mathrm{m}^{2}\right)\end{array}$ & $\begin{array}{c}\text { North } \\
(\%)\end{array}$ & $\begin{array}{c}\text { East } \\
(\%)\end{array}$ & $\begin{array}{c}\text { South } \\
(\%)\end{array}$ & $\begin{array}{c}\text { West } \\
(\%)\end{array}$ \\
\hline Ground & 92.93 & $25 \%$ & $25 \%$ & $19 \%$ & $31 \%$ \\
\hline First & 104.54 & $22 \%$ & $22 \%$ & $17 \%$ & $36 \%$ \\
\hline Second & 51.06 & $25 \%$ & $24 \%$ & $16 \%$ & $35 \%$ \\
\hline Third & 49.68 & $25 \%$ & $25 \%$ & $19 \%$ & $31 \%$ \\
\hline Fourth & 16.56 & $42 \%$ & $8 \%$ & $0 \%$ & $50 \%$ \\
\hline
\end{tabular}


The operative time of the central heating is from 7 to 18 in the winter period; two gas boilers provide both hot water for heating and DHW. The first one has a nominal power of $303.4 \mathrm{~kW}$ and the second one of $174 \mathrm{~kW}$. The number of radiators is variable inside the rooms (from 1 to 4), depending on the dimensions of the zones. Cooling system on the contrary is not central: only the first and second floor are provided with air conditioning with a different nominal power: $60.5 \mathrm{~kW}$ on the first floor and $42 \mathrm{~kW}$ on the second floor. Mono or dual fan coils with an average nominal power of $3.5 \mathrm{~kW}$ supply some offices. Finally concerning the lighting, in the offices recessed lamps with mono fluorescent tube of $58 \mathrm{~W}$ are installed while in the corridors there are 4 tubes of $18 \mathrm{~W}$ each. The height of installation is $3.5 \mathrm{~m}$. The nominal power of the entire lighting system was supposed to be about $19 \mathrm{~kW}$, including lighting power in conference rooms, laboratories and service. As a historical building, Palazzo Baleani needs a relevant energy refurbishment in order to improve envelope end technical plants performances and to reduce costs and emissions (Piras, 2016).

\section{Model description}

The model of the building in both software is composed by the same number of thermal zones (132). A thermal zone is a space or a collection of spaces having similar space-conditioning requirements and the same heating and cooling setpoint. The inputs for the characterization of the zones are the following:

\section{Climate condition}

Concerning the climatic conditions, Archsim is based on hourly profile data of EPW (EnergyPlus Weather) files, while TRNSYS includes many subroutines both for only reading standard data files (TMY and EPW) or for the implementation of new climatic profiles (TRNSYS Program guide, 2016). In this case, it was necessary to update the Archsim EPW file in order to elaborate a current EPW file of Rome, because the previous one contains old weather data. In fact, the currently climatic conditions are deep different: that is a crucial point to make an accurate simulation.

\section{Thermal zone setting}

The interface of Trnsbuild that allows to set and modify the properties of the zones: dimensions, thermo physical characteristics of the envelope and structure components, thermal load and so on. The equivalent component in Archism is "Thermal zone setting" interface. The 3D model, generated with Rhinoceros, was imported in Grasshopper as input for the "Thermal zone setting" in order to transform the geometrical model into an energy model. Thermal zone needs a specific element called "Brep" (Boundary REPresentation), useful for connecting geometrical zones together. Due to the complexity of the building composition, different components, such as Entewine, Intersector and Bang, are required in order to combine thermal zones. Consequently, the thermal zones organization could take special attention in Archsim in order to avoid geometrical errors (Figure 2).

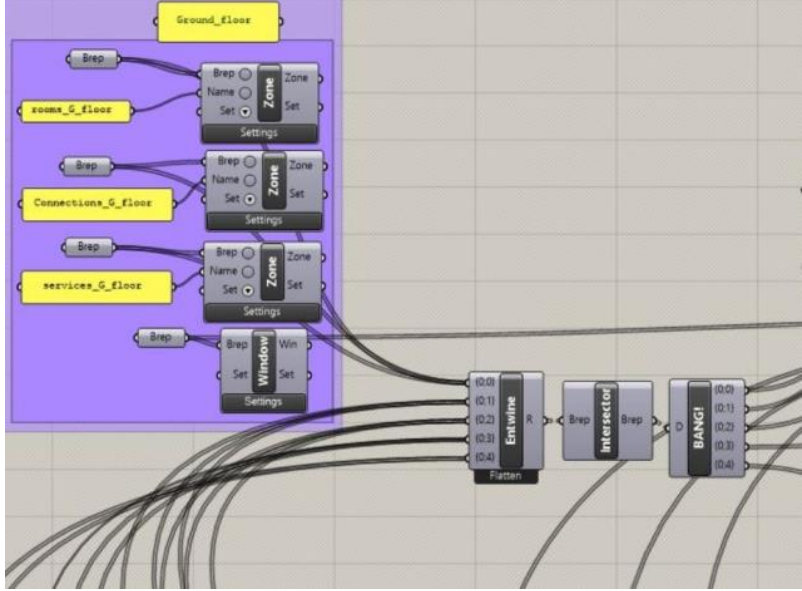

Figure 2: Archsim interface zones example

Thermal properties of the building envelope

Regarding the composition of building layers, Archsim allows to better represent the characteristics of the materials compared to TRNSYS. In fact, TRNsys provide only four parameters such as trasmittance, solar absorptance, emissivity, convective coefficient. Archism, instead, had a full schedule of proprieties: conductivity, roughness, visible absorptance, solar absorptance, emissivity, convective, transmittance.

Internal gains

Internal heat gains are the sensible and latent heat emitted from any source, as air conditioning or ventilation. The main consequence is the increase of the temperature and humidity in the space, therefore the quality of internal comfort decreased. Sources of internal loads are: lighting, people, electrical equipment (PC, printers, coffee machines). In the figures below is possible to see the schedules for internal loads of each energy tool (Figure 3, Figure 4): inputs are quite similar.

\begin{tabular}{|c|c|c|c|c|}
\hline 9 Loads & (5) Conditioning & Iit Ventilatic & ion Grat Hot Water & IS Constructions \\
\hline People & \multicolumn{4}{|c|}{$\checkmark$ On/Off } \\
\hline 0.2 & & & \multirow{2}{*}{\multicolumn{2}{|c|}{$\begin{array}{l}\text { People }[\mathrm{p} / \mathrm{m} 2] \\
\text { Schedule }\end{array}$}} \\
\hline occOffice & & $\checkmark$ & & \\
\hline Equipment & & & \multicolumn{2}{|l|}{$\checkmark$ On/Off } \\
\hline 2.2 & & & \multirow{2}{*}{\multicolumn{2}{|c|}{$\begin{array}{l}\text { Equipment [w/m2] } \\
\text { Schedule }\end{array}$}} \\
\hline equip Office & & $\checkmark$ & & \\
\hline Lighting & & & \multicolumn{2}{|l|}{$\checkmark$ On/Off } \\
\hline 5 & & & \multicolumn{2}{|l|}{ Lights [w/m2] } \\
\hline 300 & & & \multicolumn{2}{|l|}{ Target [lux] } \\
\hline Continuous & & $\checkmark$ & \multicolumn{2}{|l|}{ Dimming } \\
\hline lightsOffice & & $\checkmark$ & \multicolumn{2}{|l|}{ Schedule } \\
\hline
\end{tabular}

Figure 3: Archsim internal loads setting 


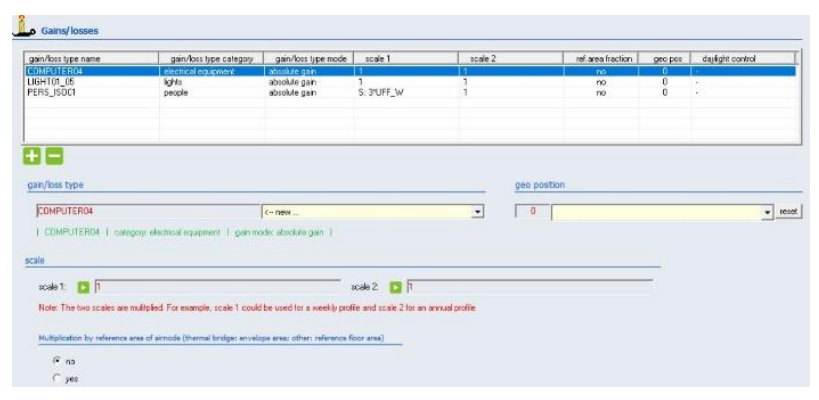

Figure 4: Trnsbuild interface internal gains

Load people

Schedules of occupancy are essential for energy and environmental simulation in order to determinate the impact of the real human presence inside the room. Both software allows to create those schedules in order to define thermal loads due to the people inside. In this case two schedules were defined: offices and classrooms, as shown in Figure 5 and Figure 6.

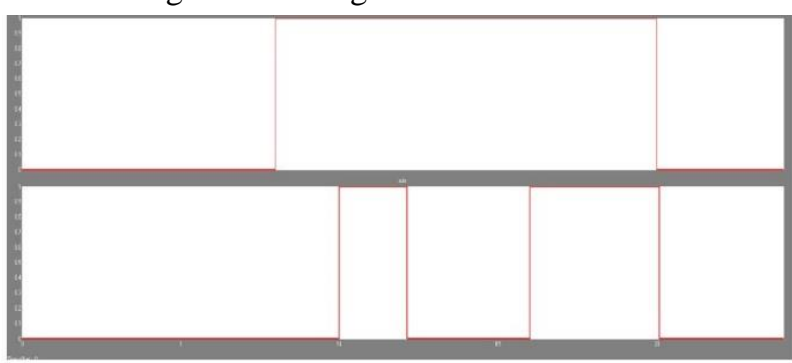

Figure 5: TRNsys offices and classrooms schedules

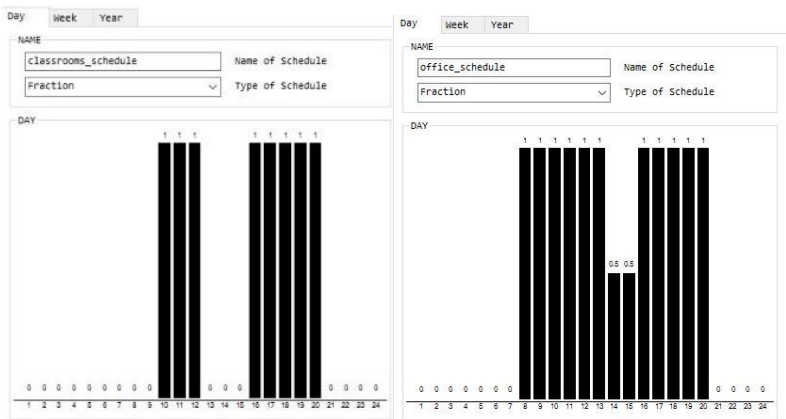

Figure 6: Archsim offices and classrooms schedules

Conditioning setting

Monthly simulations were carried out. Inputs in TRNSYS were given to set up the operative time and power of the heating and cooling systems. TRNBuild model allows to manage the operative time only through the setpoint temperature. In other words, the setpoint temperatures for winter and summer period supplied the on/off signals. In this case, several signals are combined in order to guarantee the on/off behaviour during the day and the night in different seasons. Due to this, two temperature signals are created: "Heat_T" for the heating system and "Cool_T", for the cooling system. The lack of a specific component able to create a signal depending on the simulation time could be a significant disadvantage for a not expert user. Concerning the power, the input for heating is HEAT_PW-M, which corresponds to the power supplied by a single radiator. The number of radiators, as aforementioned, is variable in each room. The cooling system is composed by internal and external fan coil units. The single power of the fan coil is COOL_PW. Climatization inputs in Archsim are the following: setpoint temperature (Figure 7) and operative time schedules of the heating and cooling systems (Figure 8). In this case, the operative time schedules of the heating and cooling systems are easier to set up than TRNsys signals codes. Archsim does not allow to set the power of the heating and cooling plants. In fact, energy simulations are carried on trough ideal technical systems due to the few energy conditioning characterizations, as shown in Figure 7.

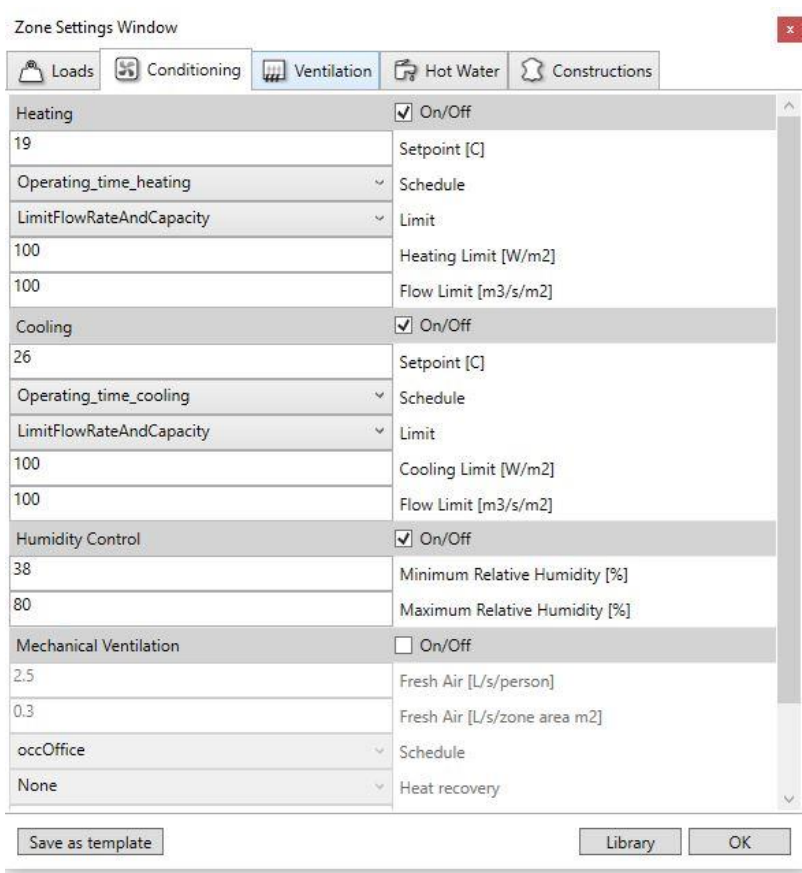

Figure 7: Archsim conditioning zone setting.

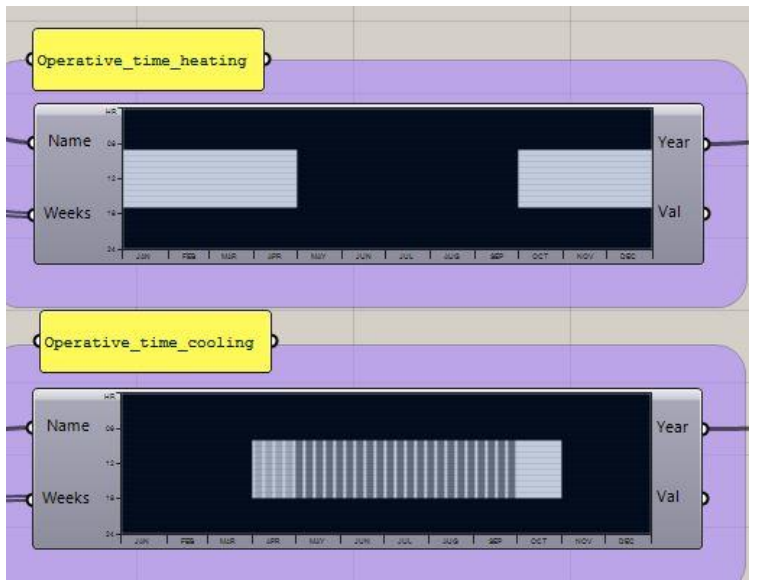

Figure 8: Archsim operative time schedules of the heating and cooling systems.

\section{Retrofit strategies}

Due to the ideal technical systems provided by Archsim, only passive retrofit strategies and photovoltaic system are simulated. TRNsys, instead, allows to design and replace active energy systems, but in this work are not consider. Therefore, in this paragraph different solutions are proposed in order to compare those energy 
simulations properly: one for the thermal efficiency and another one for the renewable energy system installation.

Reduction of energy requirements

Due to the restrictions of the listed building, only few solutions can be applied to the envelope. Windows replacement is the only solutions that respects the historical and artistical value of Palazzo Baleani. The new stratigraphy of the windows is composed by two 6 $\mathrm{mm}$ sheets of glass with an air gap of $6 \mathrm{~mm}$ too. Consequently, the transmittance value decreases from $5.4 \mathrm{~W} / \mathrm{m}^{2} \mathrm{~K}$ to $2.8 \mathrm{~W} / \mathrm{m}^{2} \mathrm{~K}$.

Photovoltaic system installation

55 monocrystalline panels of $327 \mathrm{Wp}$ and with $20,4 \%$ of efficiency are installed on the roof. TRNsys allows to manage the PV system through the Type 94 (TRNSYS 16, Mathematical Reference). It is possible to define the single panel power and to simulate the peak power trend during the year.

In Archism, the definition of the panel geometry is provided by the $3 \mathrm{D}$ model with Rhinoceros and connected through PV setting components. Panels nominal power is not available, an ideal nominal power is provided by the software. Energy DC produced is the yearly output for each panel.

\section{Results and discussion}

\section{Validation results}

Results with the two software are comparable and well aligned with real consumptions: the percentage difference is lower than $15 \%$, the mean percentage difference lower than 5\% (Table 3 and Table 4). Electricity bills show that in March the energy demand is higher than the other periods: the main reason could be the different use of the building (e.g. conferences, exhibitions and so on). The same thing happens in August where the low bills results are derived by the real occupancy of the buildings during the summer season (e.g. summer holiday). Concerning the thermal consumption, those two months report the same trend, especially regarding the DHW simulation results during August.

For validating the two software, simulations have been carried out and compared to the electricity and gas bills. Regarding the heating results (Figure 9), it possible to notice that Archsim, compared to the bills, slightly underestimates the heating demand in January, February and March while it overestimates it in October, November and December. On the other hand, Figure 10 shows the difference of the cooling energy need, where Archsim quite overestimates cooling needs in June and August. In fact, in August and March significant differences between the two energy tools are noticeable, as shown in Figure 9 and 10. In TRNSYS the percentage differences between simulation results and bills are very low both for the heating and cooling demands.

Due to the less detailed characterization of technical systems, Archsim seems incapable to described properly the thermal and cooling behaviour of those two months (August and March). On the contrary, TRNsys allows to better design technical plants, providing results in line with the real use of the building energy systems.

Table 3: Comparison between thermal consumption bills and simulations

\begin{tabular}{|c|c|c|c|c|c|}
\hline \multicolumn{6}{|c|}{ YEAR 2014} \\
\hline \multirow[b]{2}{*}{ Date/Time } & \multicolumn{3}{|c|}{ Thermal energy consumption ( $k W h$ ) } & \multicolumn{2}{|c|}{ Percentage difference $(\%)$} \\
\hline & \begin{tabular}{c|} 
Real \\
consumption
\end{tabular} & $\begin{array}{c}\text { Archsim } \\
\text { simulation }\end{array}$ & $\begin{array}{c}\text { TRNSYS } \\
\text { simualtion }\end{array}$ & $\begin{array}{c}\text { Real consumption } \\
\text { /Archsim }\end{array}$ & $\begin{array}{c}\text { Real } \\
\text { consumption / } \\
\text { TRNSYS }\end{array}$ \\
\hline January & 51606,8 & 47561,75 & 50337,02 & $7,84 \%$ & $2,46 \%$ \\
\hline February & 39019,9 & 36965,06 & 40017,1 & $5,27 \%$ & $2,56 \%$ \\
\hline March & 32923,8 & 29016,90 & 31988,2 & $11,87 \%$ & $2,84 \%$ \\
\hline April & 5039 & 5474,07 & 5185,8 & $8,63 \%$ & $2,91 \%$ \\
\hline May & 342,5 & 358,00 & 335 & $4,53 \%$ & $2,19 \%$ \\
\hline June & 277,4 & 277,00 & 275 & $0,14 \%$ & $0,87 \%$ \\
\hline July & 264,4 & 287,00 & 261 & $8,55 \%$ & $1,29 \%$ \\
\hline August & 255,4 & 287,00 & 248 & $12,37 \%$ & $2,90 \%$ \\
\hline September & 281,1 & 277,00 & 283 & $1,46 \%$ & $0,68 \%$ \\
\hline October & 1388,6 & 1448,00 & 1354 & $4,28 \%$ & $2,49 \%$ \\
\hline November & 11830,7 & 12728,06 & 11655,1 & $7,59 \%$ & $1,48 \%$ \\
\hline December & 36038,3 & 36902,00 & 35971,2 & $2,40 \%$ & $0,19 \%$ \\
\hline \multicolumn{4}{|c|}{ Total thermal energy consumption (kWh) year 2014} & \multicolumn{2}{|c|}{ Mean percentage difference (\%) } \\
\hline Total & 179267,9 & 171581,84 & 177910,42 & $6,24 \%$ & $1,90 \%$ \\
\hline
\end{tabular}

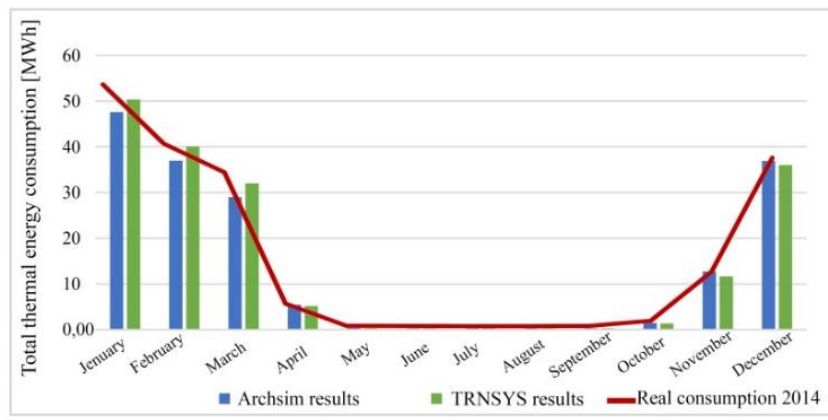

Figure 9: Archsim, TRNsys and real thermal consumptions 2014 graphic

Table 4: Comparison between electrical consumption bills and simulations

\begin{tabular}{|c|c|c|c|c|c|}
\hline \multicolumn{6}{|c|}{ YEAR 2014} \\
\hline \multirow[b]{2}{*}{ Date/Time } & \multicolumn{3}{|c|}{ Electric consumption (kWh) } & \multicolumn{2}{|c|}{ Percentage difference (\%) } \\
\hline & $\begin{array}{c}\text { Real } \\
\text { consumption }\end{array}$ & $\begin{array}{l}\text { Archsim } \\
\text { simulation }\end{array}$ & $\begin{array}{c}\text { TRNSYS } \\
\text { simulation }\end{array}$ & $\begin{array}{c}\text { Real } \\
\text { consumption } \\
\text { /Archsim }\end{array}$ & $\begin{array}{c}\text { Real } \\
\text { consumption / } \\
\text { TRNSYS }\end{array}$ \\
\hline January & 4082,60 & 3847,55 & 4026,60 & $5,76 \%$ & $1,37 \%$ \\
\hline February & 3586,70 & 3475,20 & 3462,92 & $3,11 \%$ & $3,45 \%$ \\
\hline March & 4569,60 & 3888,55 & 4528,73 & $14,90 \%$ & $0,89 \%$ \\
\hline April & 4465,70 & 4642,86 & 4354,88 & $3,97 \%$ & $2,48 \%$ \\
\hline May & 11423,00 & 10538,58 & 11463,16 & $7,74 \%$ & $0,35 \%$ \\
\hline June & 13477,80 & 13940,31 & 13499,44 & $3,43 \%$ & $0,16 \%$ \\
\hline July & 15190,40 & 16127,66 & 15442,21 & $6,17 \%$ & $1,66 \%$ \\
\hline August & 14606,30 & 16353,27 & 14564,37 & $11,96 \%$ & $0,29 \%$ \\
\hline September & 14602,90 & 13955,99 & 14211,39 & $4,43 \%$ & $2,68 \%$ \\
\hline October & 10238,80 & 9841,48 & 10249,08 & $3,88 \%$ & $0,10 \%$ \\
\hline November & 3825,10 & 3723,43 & 3727,27 & $2,66 \%$ & $2,56 \%$ \\
\hline December & 3650,20 & 3847,55 & 3606,49 & $5,41 \%$ & $1,20 \%$ \\
\hline \multicolumn{4}{|c|}{ Total electric consumption (kWh) year 2014} & \multicolumn{2}{|c|}{ Mean percentage difference } \\
\hline Total & 103719,10 & 100334,89 & 99109,94 & $6,15 \%$ & $1,44 \%$ \\
\hline
\end{tabular}

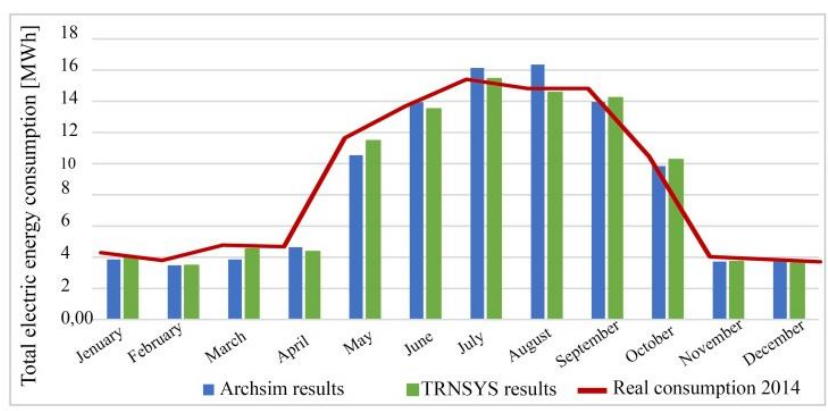




\section{Figure 10: Archsim, TRNsys and real electrical consumptions 2014 graphic}

\section{nZEBs pre and post retrofit results}

Table 5 shows the achievement of nZEBs targets before the interventions. It is evident that some of nZEBs requirements are satisfied, as green boxes highlighted. The rest of targets are quite distance from the minimum requirement, due to the low performances of the envelope and low efficiencies of the energy plant.

Table 5: Scenario nZEBs pre-retrofit

\begin{tabular}{|c|c|c|c|c|}
\hline \multicolumn{5}{|c|}{ target Nzeb } \\
\hline \multirow[b]{2}{*}{ Parameters } & \multirow[b]{2}{*}{ u.m. } & \multirow[b]{2}{*}{ Requirements } & \multicolumn{2}{|c|}{ Pre retrofit } \\
\hline & & & ARCHSIM & TRYNSYS \\
\hline $\mathrm{H}^{\prime} \mathrm{t}$ & $\mathrm{W} / \mathrm{m}^{2} \mathrm{~K}$ & $\leq 0,68$ & 1,15 & 1,15 \\
\hline$A_{\text {solesst }} / A_{\text {sup utile }}$ & n.d. & $\leq 0,04$ & 0,038 & 0,038 \\
\hline$\eta_{н}$ & $\%$ & $\geq 0,81$ & 0,78 & 0,78 \\
\hline$E p_{H, n d}$ & $\mathrm{kWh} / \mathrm{m}^{2}$ & $\leq 64,28$ & 109,34 & 105,14 \\
\hline$E p_{H}$ & $\mathrm{kWh} / \mathrm{m}^{2}$ & $\leq 61,22$ & 120,11 & 124,54 \\
\hline$n_{c}$ & $\%$ & $\geq 0,81$ & 0,85 & 0,85 \\
\hline$E p_{C, n d}$ & $\mathrm{kWh} / \mathrm{m}^{2}$ & $\leq 45,22$ & 83,63 & 84,51 \\
\hline$E p_{C}$ & $\mathrm{kWh} / \mathrm{m}^{2}$ & $\leq 45,22$ & 79,28 & 80,11 \\
\hline$\eta_{w}$ & $\%$ & $\geq 0,70$ & 0,78 & 0,78 \\
\hline$E p_{W, n d}$ & $\mathrm{kWh} / \mathrm{m}^{2}$ & $\leq 6,43$ & 6,15 & 6,00 \\
\hline$E p_{w}$ & $\mathrm{kWh} / \mathrm{m}^{2}$ & $\leq 6,12$ & 6,12 & 6,00 \\
\hline$E p_{L}$ & $\mathrm{kWh} / \mathrm{m}^{2}$ & $\leq 26,15$ & 43,08 & 45,01 \\
\hline$E p_{t}$ & $\mathrm{kWh} / \mathrm{m}^{2}$ & $\leq 2,50$ & 2,20 & 2,10 \\
\hline $\boldsymbol{E} \boldsymbol{p}_{v}$ & $\mathrm{kWh} / \mathrm{m}^{2}$ & & o service & \\
\hline$E p_{g l, t o t}$ & $\mathrm{kWh} / \mathrm{m}^{2}$ & $\leq 141,21$ & 250,79 & 257,76 \\
\hline
\end{tabular}

Table 6 shows the results obtained with the energy strategies: windows replacement provides a significant thermal energy reduction, quite similar with both software (Archsim results are 3\% higher than TRNsys). Concerning the cooling supply, both software registered an energy demand increase, especially TRNsys, related to their calculation algorithms of the envelope insulation improvement.

Table 6: Simulations results for each retrofit solution

\begin{tabular}{|c|c|c|}
\hline Windows retrofit & \multicolumn{2}{|c|}{ Total thermal energy (kWh) 2014 } \\
\hline Software & Archsim & Trnsys \\
\hline pre & 171581,84 & 177910,42 \\
\hline post & 127406,74 & 136790 \\
\hline$\Delta \%$ & $26 \%$ & $23 \%$ \\
\hline Windows retrofit & Total cooling energy (kWh) 2014 \\
\hline Software & Archsim & Trnsys \\
\hline pre & 60985,75 & 61625,8 \\
\hline post & 61408 & 72480 \\
\hline$\Delta \%$ & $-1 \%$ & $-18 \%$ \\
\hline PV system retrofit & Electric energy produced (kWh/year) \\
\hline Software & Archsim & Trnsys \\
\hline pre & no service & no service \\
\hline post & 17314,00 & 23058,00 \\
\hline
\end{tabular}

Regarding the achievement of nZEBs requirements after the interventions, new windows properties do not allow to satisfy the $H^{\prime}{ }_{T}$ (mean global thermal trasmittance per dispersive surfaces) target, due to the building restrictions (Table 7). The $E p_{H}$ and $E p_{H, n d}$ decrease the previous value because the heating energy need is reduced by the new glass stratigraphy, but this change is not enough. On contrary, the cooling demand for both software is slightly increased due to the improvement of envelope insulation, as the and indicators shown.

Table 7: scenario $n Z E B$ s post windows retrofit

\begin{tabular}{|c|c|c|c|c|}
\hline \multicolumn{5}{|c|}{ target Nzeb } \\
\hline \multirow{2}{*}{ Parameters } & \multirow{2}{*}{ u.m. } & \multirow{2}{*}{ Requirements } & \multicolumn{2}{|c|}{ Post windows retrofit } \\
\hline & & & ARCHSIM & TRYNSYS \\
\hline$H^{\prime} t$ & $\mathrm{~W} / \mathrm{m}^{2} \mathrm{~K}$ & $\leq 0,68$ & 0,95 & 0,95 \\
\hline $\mathbf{A}_{\text {solesst/ }} \mathbf{A}_{\text {sup vutle }}$ & n.d. & $\leq 0,04$ & 0,038 & 0,038 \\
\hline$\eta_{H}$ & $\%$ & $\geq 0,81$ & 0,78 & 0,78 \\
\hline$E p_{H, n d}$ & $\mathrm{kWh} / \mathrm{m}^{2}$ & $\leq 64,28$ & 69,6 & 74,69 \\
\hline$E p_{H}$ & $\mathrm{kWh} / \mathrm{m}^{2}$ & $\leq 61,22$ & 89,18 & 95,75 \\
\hline$\eta_{c}$ & $\%$ & $\geq 0,81$ & 0,85 & 0,85 \\
\hline$E p_{C, n d}$ & $\mathrm{kWh} / \mathrm{m}^{2}$ & $\leq 45,22$ & 84,46 & 99,40 \\
\hline$E p_{C}$ & $\mathrm{kWh} / \mathrm{m}^{2}$ & $\leq 45,22$ & 80,12 & 94,23 \\
\hline$\eta_{w}$ & $\%$ & $\geq 0,70$ & 0,78 & 0,78 \\
\hline$E p_{W, n d}$ & $\mathrm{kWh} / \mathrm{m}^{2}$ & $\leq 6,43$ & 6,15 & 6,00 \\
\hline$E p_{w}$ & $\mathrm{kWh} / \mathrm{m}^{2}$ & $\leq 6,12$ & 6,12 & 6,00 \\
\hline$E p_{L}$ & $\mathrm{kWh} / \mathrm{m}^{2}$ & $\leq 26,15$ & 43,08 & 45,01 \\
\hline$E p_{t}$ & $\mathrm{kWh} / \mathrm{m}^{2}$ & $\leq 2,50$ & 2,20 & 2,10 \\
\hline$E \boldsymbol{p}_{v}$ & $\mathrm{kWh} / \mathrm{m}^{2}$ & \multicolumn{3}{|c|}{ no service } \\
\hline$E p_{\text {gl,tot }}$ & $\mathrm{kWh} / \mathrm{m}^{2}$ & $\leq 141,21$ & 220,71 & 243,09 \\
\hline
\end{tabular}

In Table 8, nZEBs targets achieved with the PV solution are summarized. Following the 26/06/2015 Italian Ministerial Decree (2015), energy produced with the photovoltaic system can be used for the lighting requirements of the non-residential building, as the case study. With both the energy tools the $E P_{l}$ target (lighting performance energy index) has been obtained. The nominal electrical renewable power as $P_{\text {el.ren }}$, required by the 28/11/2011 Italian Legislative Decree (2011) can't be defined in Archsim due to the impossibility to set the capacity of the PV system.

Table 8: scenario $n Z E B s$ post pv system retrofit

\begin{tabular}{|c|c|c|c|c|}
\hline \multicolumn{5}{|c|}{ target Nzeb } \\
\hline \multirow{2}{*}{ Parameters } & \multirow{2}{*}{ u.m. } & \multirow{2}{*}{ Requirements } & \multicolumn{2}{|c|}{ Post PV retrofit } \\
\hline & & & ARCHSIM & TRYNSYS \\
\hline$H^{\prime}{ }_{T}$ & $\mathrm{~W} / \mathrm{m}^{2} \mathrm{~K}$ & $\leq 0,68$ & 0,95 & 0,95 \\
\hline$A_{\text {sole,est }} / A_{\text {sup utile }}$ & n.d. & $\leq 0,04$ & 0,038 & 0,038 \\
\hline$\eta$ н & $\%$ & $\geq 0,81$ & 0,78 & 0,78 \\
\hline$E p_{H, n d}$ & $\mathrm{kWh} / \mathrm{m}^{2}$ & $\leq 64,28$ & 109,34 & 105,14 \\
\hline$E p_{H}$ & $\mathrm{kWh} / \mathrm{m}^{2}$ & $\leq 61,22$ & 120,11 & 124,54 \\
\hline$n_{c}$ & $\%$ & $\geq 0,81$ & 0,85 & 0,85 \\
\hline$E p_{C, n d}$ & $\mathrm{kWh} / \mathrm{m}^{2}$ & $\leq 45,22$ & 83,63 & 84,51 \\
\hline$E p_{C}$ & $\mathrm{kWh} / \mathrm{m}^{2}$ & $\leq 45,22$ & 98,39 & 99,42 \\
\hline$\eta w$ & $\%$ & $\geq 0,70$ & 0,78 & 0,78 \\
\hline$E p_{W, n d}$ & $\mathrm{kWh} / \mathrm{m}^{2}$ & $\leq 6,43$ & 6,15 & 6,00 \\
\hline$E p_{W}$ & $\mathrm{kWh} / \mathrm{m}^{2}$ & $\leq 6,12$ & 6,12 & 6,00 \\
\hline$E p_{L}$ & $\mathrm{kWh} / \mathrm{m}^{2}$ & $\leq 26,15$ & 26,00 & 22,26 \\
\hline$E p_{t}$ & $\mathrm{kWh} / \mathrm{m}^{2}$ & $\leq 2,50$ & 2,20 & 2,10 \\
\hline$E \boldsymbol{p}_{v}$ & $\mathrm{kWh} / \mathrm{m}^{2}$ & & service & \\
\hline$E p_{\text {gl,tot }}$ & $\mathrm{kWh} / \mathrm{m}^{2}$ & $\leq 141,21$ & 252,81 & 252,22 \\
\hline$P_{e l, r e n}$ & $\mathrm{~kW}$ & $\leq 17,5$ & - & 18 \\
\hline
\end{tabular}




\section{Conclusion}

This study highlights different aspects of those energy tools. In the first part, concerning the comparison between the real consumption and the simulations results, it is evident that both tools gave similar results and aligned with real consumptions. It means that energy needs are adequately estimated with the two software, except for particular months.

Regarding the first retrofit solution, the window replacement, Archsim as an architectural energy tool, provides an accurate materials and envelope analysis: that are the primary properties of this software. Therefore, it allows to obtain comparable results with TRNsys. The second solution highlights that TRNsys is more suitable for the technical system modelling providing the nominal electrical renewable power $\left(P_{\text {el.ren }},\right)$ for the PV system which is not available on Archsim

The use of those energy tools also depends on the available data and the targets of the user: If real consumptions are not provided, Archsim is a good choice, using the energy primary requirement related to ideal technical plants performances. If real consumptions are available, TRNsys can be chosen due to its accuracy in modelling technical plants. The weakness and strength, discussed in this paper, have the aim to be a general guide for the users. Regarding the simulation of nZEBs TRnsys appears more suitable than Archsim, as shown in Table 8.

Limits of Archsim emerged in this study will be further investigated. In particular in future works it will be analysed if the use of additional Grasshopper tools will allow to reduce the difference between an open-source architectural software and a transient engineering software.

\section{Nomenclature}

$H_{T}^{\prime}=$ mean global thermal trasmittance per dispersive surfaces $\left(\mathrm{W} / \mathrm{m}^{2} \mathrm{~K}\right)$.

$A_{\text {sol }, \text { est }} / A_{\text {sup } u t i l e}=$ The solar equivalent area per useful surfaces (n.d.).

$\eta_{H}=$ Technical heating system mean efficiency (\%).

$E p_{H, n d}=$ Heating need performance energy index $\left(\mathrm{kWh} / \mathrm{m}^{2}\right)$.

$E p_{H}=$ Heating system performance energy index $\left(\mathrm{kWh} / \mathrm{m}^{2}\right)$.

$\eta_{C}=$ Technical cooling system mean efficiency $(\%)$.

$E p_{C, n d}=$ Cooling need performance energy index $\left(\mathrm{kWh} / \mathrm{m}^{2}\right)$

$E p_{C}=$ Cooling system performance energy index. $\left(\mathrm{kWh} / \mathrm{m}^{2}\right)$.

$\eta_{W}=$ Technical hot water system mean efficiency (\%).

$E p_{w, n d}=$ Hot water need performance energy index $\left(\mathrm{kWh} / \mathrm{m}^{2}\right)$.

$E p_{W}=$ Hot water system performance energy index $\left(\mathrm{kWh} / \mathrm{m}^{2}\right)$.
$E p_{t}=$ Transport people service performance energy index $\left(\mathrm{kWh} / \mathrm{m}^{2}\right)$.

$E P_{l}=$ Lighting performance energy index $\left(\mathrm{kWh} / \mathrm{m}^{2}\right)$.

$E p_{v}=$ Ventilation performance energy index $\left(\mathrm{kWh} / \mathrm{m}^{2}\right)$.

$E p_{g l, t o t}=$ The total primary energy $\left(\mathrm{kWh} / \mathrm{m}^{2}\right)$.

$P_{\text {el.ren }}=$ nominal electrical renewable power $(\mathrm{kW})$.

\section{References}

Alstan Jakubiec, J., \& Reinhart, C.F. (2011) DIVA 2.0: Integrating daylight and thermal simulations using Rhinoceros 3D, Daysim and EnergyPlus. 12th Conference of International Performance Simulation Association, Sydney, 14-16 November 2011.

Decreto Legislativo (2011). Attuazione della direttiva 2009/28/CE sulla promozione dell'uso dell'energia da fonti rinnovabili, recante modifica e successiva abrogazione delle direttive 2001/77/CE e 2003/30/CE (D.Lgs. 3/03/2011).

Decreto Ministeriale (2015). Attuazione della direttiva 2010/31/UE per la promozione degli edifici a energia quasi zero (D.M. 16/06/2015).

Dogan, T. (2013). Archsim Energy Modeling Software. Retrieved November 1 2013, from http://www.archsim.com/

Dogan, T., Reinhart, C. F., Saratsis, E. (2015). Toward an energy simulation-informed process: a 3-phase approach for a performative interdisciplinary phase approach for a performative interdisciplinary laboratory building. Building Simulation Conference 2015, Hyderabad (USA), December, 2015.

EERE. (2013). EnergyPlus Energy Simulation Software.

EERE U.S. Department of Energy. Retrieved November 1,2013,from:http://apps1.eere.energy.gov/buildings/e nergyplus/

European Parliament Directive (2010). Energy performance of buildings (recast), Official Journal of The European Union (2010/31/EU).

Gasparella, A., \& Pernigotto, G. (2010) Analisi comparativa dei codici di simulazione dinamica degli edifici: un confronto tra TRNsys ed EnergyPlus. $65^{\circ}$ Congresso Nazionale ATI - Cagliari (IT), 13-17 September 2010

Mauri, L. (2016). Feasibility analysis of retrofit strategies for the achievement of NZEB target on a historic building for tertiary use. $71^{\text {st }}$ Conference of the Italian Thermal Machines Engineering Association, Turin (IT), 14-16 September 2016.

Mazzarella, L. (2015). Energy retrofit of historic and existing buildings. The legislative and regulatory point of view. Energy and Buildings, 2015, 23-31.

Neymark J. and R. Judkoff, (2008). International Energy Agency Building Energy Simulation Test and Diagnostic Method (IEA BESTEST). In-Depth Diagnostic Cases for Ground coupled heat Transfer 
Related to Slab-on-Grade Construction. NREL/TP550-43388,2008.

Piras, G., Romeo, C., Nardecchia, F., Rosa, F., Barbanera, F., (2016). Diagnosi energetica di un edificio vincolato rappresentativo uso uffici della PA sottoposto a riqualificazione energetica nZEBs, zona climatica D, Centro Italia, e analisi economica degli interventi proposti. ENEA, Report 2016.

Presidenza Repubblica Italiana, Decreto Legislativo 22 Gennaio 2004, n. 42, Codice dei beni culturali e del paesaggio, ai sensi dell'articolo 10 Legge 6 Luglio 2002, n. 137. GU n. 45 del 24-2-2004- Suppl. Ordinario n. 28.

Solar Energy Laboratory; TRNSYS Program guide: Weather data, Madison: University of WinsconsinMadison, 2016.

Testi, D., Rocca, M., Menchetti, E., Comelato, S. (2017). Criticalities in the NZEB retrofit of scholastic buildings: analysis of a secondary school in Centre Italy. AiCARR 50 ${ }^{\text {th }}$ International Congress Beyond NZEB buildings. Matera (IT), 10-11 May 2017.

TRNSYS 16 a TRaNs i e $\mathrm{n}$ SYstem Si m u 1 a t i o n p r o g r a m, Manual.

TRNSYS 16 a TRaNs i e n t SYstem Si m u l a t i o n p r o g r a m, Volume 5, Mathematical Reference.

UNI/TS 11300-1:2014, Prestazioni energetiche degli edifici - Parte 1: Determinazione del fabbisogno di energia termica dell'edificio per la climatizzazione estiva ed invernale. 